\title{
Egg production of the burrowing shrimp Callichirus seilacheri (Bott 1955) (Decapoda, Callianassidae) in northern Chile
}

\author{
Patricio Hernáez $\cdot$ Sergio Palma $\cdot$ Ingo S. Wehrtmann
}

Received: 29 November 2007 / Revised: 6 May 2008/ Accepted: 30 June 2008 / Published online: 23 July 2008

(C) Springer-Verlag and AWI 2008

\begin{abstract}
The thalassinidean shrimp Callichirus seilacheri is a common species in the intertidal zone of the South American Pacific coast. However, our knowledge of its reproductive ecology is rather limited. The present study was carried out between January and December 2003 at Las Machas, northern Chile. Although ovigerous females were encountered almost throughout the study period, they were particularly abundant between May and September when water temperatures were lowest and sediment coverage of the burrow entrances was highest. Females of $C$. seilacheri produced numerous (17,450 $\pm 3,796$ eggs $)$ and small $\left(0.884 \pm 0.080 \mathrm{~mm} ; \quad 0.262 \pm 0.054 \mathrm{~mm}^{3}\right) \quad$ eggs when compared to other thalassinidean shrimps for which such information is available. Fecundity was positively correlated with female size; however, correlations were allometric, which might be related to the elasticity of the abdomen. Egg volume increased by $41.2 \%$ during embryogenesis, and egg loss during the incubation period
\end{abstract}

Communicated by H.-D. Franke.

\section{P. Hernáez}

Museo del Mar, Universidad Arturo Prat,

Casilla 121, Iquique, Chile

e-mail: phernaez@lycos.com

\section{S. Palma}

Escuela de Ciencias del Mar,

Pontificia Universidad Católica de Valparaíso,

Casilla 1020, Valparaíso, Chile

e-mail: spalma@ucv.cl

\section{S. Wehrtmann $(\square)$}

Unidad de Investigación Pesquera y Acuicultura (UNIP) of the Centro de Investigaciones en Ciencias del Mar y Limnología (CIMAR), Universidad de Costa Rica, 2060 San José, Costa Rica e-mail: ingowehrtmann@gmx.de was on average $8 \%$. Females inverted on average $14.9 \%$ of their dry weight into egg production.

Keywords Fecundity - Reproductive output - Accretion · Callianassidae $\cdot$ Northern Chile $\cdot$ Egg loss

\section{Introduction}

The shrimps of the Infraorder Thalassinidea are considered as engineering organism due to their capacity to build complex networks of galleries below the surface (Berkenbusch and Rowden 2003). Their life cycle, except for the larval phase usually proceeds in cryptic habitats which may explain at least partially the lack of available information on the reproductive ecology of most of its representatives. During the last decade, our knowledge about several aspects of the life history of thalassinidean shrimps has increased significantly (e.g. Kevrekidis et al. 1997; Nates and Felder 1999; Berkenbusch and Rowden 2000; Bilodeau et al. 2005; Hernáez and Wehrtmann 2007). However, information especially on egg production and energy investment for reproduction remained limited.

Female size explains only part of the observed variability in the fecundity of thalassinidean shrimps; the correlation coefficient $(r)$ reported for some species of this group (e.g. Hanekom and Erasmus 1989; Souza et al. 1998; Berkenbusch and Rowden 2000) is usually considerably lower than that observed in brachyuran and anomuran decapods (Hines 1991; Corey and Reid 1991; Reid and Corey 1991). It is assumed that the cryptic life may bring about an important egg loss while females move around in the galleries, thus explaining the relatively low correlation between female size and egg production (Thessalou and Kiortsis 1997). 
Egg size is one of the most variable parameter in decapods and offers valuable information on a species' reproductive strategy. It is a useful indicator of the duration of embryogenesis and larval size at hatching (Steele and Steele 1975). Moreover, several studies on thalassinidean shrimps showed a clear relation between egg size and type of larval development (Forbes 1973; Felder and Griffis 1994; Thessalou et al. 1999). Such information, however, is restricted to just a few thalassinidean species.

The energy inverted in reproduction of decapods can be described as reproductive output (RO, Pianka 1972). Although this value varies among species and even within the same species (Wehrtmann and Kattner 1998), it is assumed that many female decapods devote around $10 \%$ of their body weight to the production of eggs (Hines 1982, 1991; Lardies and Wehrtmann 1996; Hernáez and Palma 2003; Brante et al. 2004). The RO in unknown for the majority of thalassinidean shrimps, particularly for those species inhabiting the southeast Pacific coast.

Considering thalassinidean shrimps of the Americas, representatives of the genus Callichirus Stimpson, 1866 are a common element of the intertidal and subtidal zone of some sandy beaches (Felder and Griffis 1994). Currently, this genus comprises three species; however, only C. seilacheri Bott 1955 (=C. garthi; Retamal 1975; see Sakai $1999)$ can be found along the eastern Pacific coast $\left(12^{\circ} \mathrm{N}-\right.$ $37^{\circ} \mathrm{S}$; Sakai 1999). Both the life cycle and the population dynamics of $C$. seilacheri seems to be strongly influenced by temperature and sediment movements (Hernáez and Wehrtmann 2007). Despite of the fact that this species is characteristic of many sandy beaches along the Chilean coast (Aste and Retamal 1983), its reproductive biology is completely unknown, a situation similar to that in most other thalassinideans of the Americas. The present study analyzed fecundity, egg characteristics, and RO of C. seilacheri. Additionally, we compiled and compared the published information about the reproduction of other thalassinideans which may facilitate a better comprehension of the reproductive strategies of these burrowing shrimps.

\section{Methods}

\section{Study area}

Shrimps were collected monthly from January to December 2003 in the intertidal zone of the beach Las Machas, northern Chile $\left(18^{\circ} 25^{\prime} \mathrm{S}-70^{\circ} 19^{\prime} \mathrm{W}\right)$. This sector is characterized by fine sediments of terrigenous origin, supplied by the rivers Lluta and San José (Soto et al. 2002). The beach is wide open and influenced by high energy waves, especially during autumn (April-June) and winter (JulySeptember). The physical structure of the beach shows a seasonal pattern with the formation of wide intertidal plains during the summer, and an increased accretion during autumn and winter (Hernáez and Wehrtmann 2007). The presence of $C$. seilacheri is restricted to the area between the rivers Lluta and San José (approximately $8 \mathrm{~km}$ ), with high gallery densities in the intertidal zone (P. Hernáez, pers. obs.).

\section{Analyses of material}

Specimens were collected with a yabby pump (diameter: $77 \mathrm{~mm}$ ), and surface water temperature was measured to $\pm 0.1^{\circ} \mathrm{C}$. Ovigerous females were put into individual plastic bags and transported to the laboratory of the Universidad Arturo Prat in Iquique, northern Chile. The following parameters were measured for each individual: total length (TL; $\pm 0.1 \mathrm{~mm}$; from anterior carapace margin to posterior region of telson), carapace length $(\mathrm{CL} ; \pm 0.1 \mathrm{~mm}$; from anterior to posterior carapace margin) and wet weight $( \pm 0.1 \mathrm{~g})$.

We detached the total egg mass from the ovigerous female and separated three subsamples of 100 eggs each, which were dried for $48 \mathrm{~h}$ at $65^{\circ} \mathrm{C}$ together with the remaining egg mass. Subsequently, each subsample and the remaining egg mass were weighed on an analytical balance (Sartorius; $\pm 0.1 \mathrm{mg}$ ). Egg weight and total egg number were calculated according to the following equations:

$E=S / 100$

$\mathrm{NE}=\mathrm{OM} / E$

with $E=$ egg weight, $S=$ average weight of subsample, $\mathrm{NE}=$ total egg number; $\mathrm{OM}=$ weight of total egg mass.

Developing eggs of $C$. seilacheri were classified into three stages (Stage I-III) considering shape and the development of both abdomen and eyes as described by Wehrtmann (1990). We separated arbitrarily 20 eggs from the egg mass and measured the width and length of each egg under a microscope equipped with a calibrated ocular micrometer. These data were used to calculate egg volume (EV) according to the formula proposed by Turner and Lawrence (1979) for oblate spheroids: $\mathrm{EV}=1 / 6$ $\left(a \times b^{2} \times \pi\right)$, where $a$ represents length, and $b$ width.

The RO was estimated exclusively for females carrying recently produced eggs (Stage I), applying the formula proposed by Clarke et al. (1991):

RO $=\frac{\text { dry weight of the entire egg mass }}{\text { dry weight of the female without eggs }}$.

Data analyses

The relation between fecundity and female size is described by an allometric model $\left(Y=a X^{b}\right)$, which has been used widely for this purpose in similar studies on other 
decapods (e.g. Hines 1991; Corey and Reid 1991; Hernáez and Palma 2003). According to Somers (1991), an isometric relation is indicated by values for $b$ near to 3 . Thus, $b$ values of $<2.90$ and $>3.10$ were taken as indication of a negative and positive allometric relation, respectively (see Hernáez and Wehrtmann 2007). An analysis of covariance (ANCOVA; Zar 1999) was applied to the relation between egg number and CL for each embryonic stage to estimate egg loss during the incubation period. In case of a significant difference $(P<0.05)$, a Tukey a posteriori test was used to establish the similarity between each pair of developmental stages (Zar 1999).

\section{Results}

A total of 716 individuals of $C$. seilacheri were analyzed. Forty-eight of them revealed as ovigerous females $(6.7 \%)$ with CL ranging from 18.6 to $23.2 \mathrm{~mm}$ (average $21.7 \pm 0.83 \mathrm{~mm}$ ). A majority of the ovigerous females (95\%) measured between 20 and $23 \mathrm{~mm}$ CL.

The number of eggs carried by the females varied between 9,612 and 25,550 (average: 17,450 \pm 3,796). The fecundity increased significantly with both female size and weight (Table 1). Correlation was relatively low, except for CL where the coefficient was almost 90\% (Fig. 1). All relations tested to explain egg production in $C$. seilacheri tended to be allometric (Table 1). Considering exclusively females with eggs of Stages I and II, fecundity tended to be higher and egg volume to be smaller in the cold than in the warm period (fecundity, June-September: 18,278 \pm 3,905 eggs; November-May: 16,718 \pm 4,775 eggs; egg volume, June-September: $0.227 \pm 0.031 \mathrm{~mm}^{3}$; November-May: $0.243 \pm 0.017 \mathrm{~mm}^{3}$ ). However, differences in both fecundity and volume of egg were not statistically significant ( $t$ test, $P>0.05)$.

Table 1 Ovigerous females of Callichirus seilacheri

\begin{tabular}{llll}
\hline Equation & $R$ & $R^{2}$ & $N$ \\
\hline Fecundity versus size/wet weight & & & \\
1. $\log \mathrm{NE}=2.621+1.654 \log \mathrm{CL}$ & 0.897 & 0.805 & $48^{*}$ \\
2. $\log \mathrm{NE}=1.672+1.271 \log \mathrm{TL}$ & 0.536 & 0.288 & $48^{*}$ \\
3. $\log \mathrm{NE}=3.680+0.304 \log \mathrm{WW}$ & 0.528 & 0.278 & $48^{*}$ \\
Wet weight versus body size & & & \\
4. $\log \mathrm{WW}=0.893+1.974 \log \mathrm{CL}$ & 0.618 & 0.382 & $48^{*}$ \\
5. $\log \mathrm{WW}=0.145+3.269 \log \mathrm{TL}$ & 0.796 & 0.634 & $48^{*}$ \\
\hline
\end{tabular}

Allometric regression equations for the estimation of egg production $R$ correlation coefficient, $R^{2}$ determination coefficient, $N$ number of females analyzed, $C L$ carapace length, $N E$ number of eggs, $T L$ total length, $W W$ wet weight

* Statistically significant $(P>0.05)$

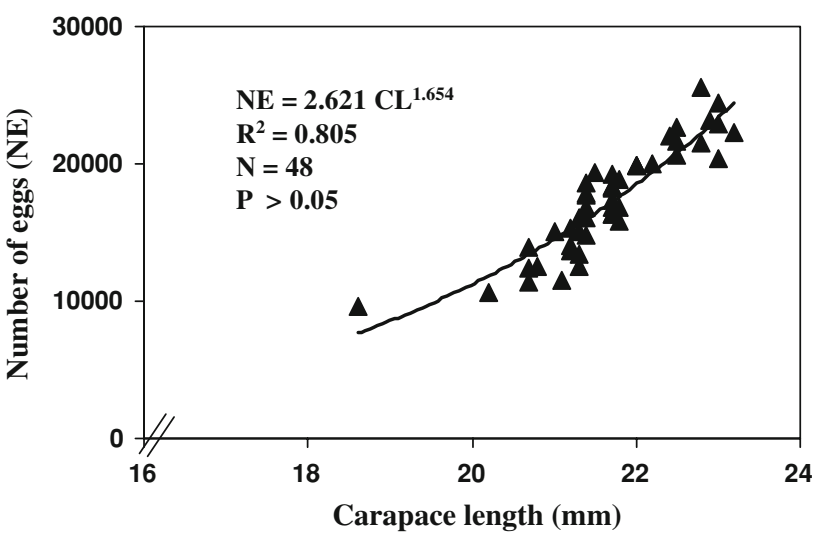

Fig. 1 Relation between carapace length $(C L)$ and number of eggs $(N E)$ of ovigerous females of Callichirus seilacheri from northern Chile

Ovigerous females were encountered almost throughout the study period, with the exception of January-February and October. The highest frequency of egg bearing females was observed from May to September, when mean water temperatures were lowest (Table 2). The vast majority of females with recently extruded eggs (Stage I: 92\%) was collected between May and July, when water temperature started to decline (Table 2).

During the incubation period, females of $C$. seilacheri lose $8 \%$ of their initially produced eggs (ANCOVA, $f=3.38 ; P<0.05)$. No statistically significant differences were detected between numbers of eggs carried by females with eggs in Stages I and II; however, females with eggs in Stage III carried significantly lower numbers of eggs than females with eggs in Stages I and II, respectively (Tukey test, $P<0.05)$. During embryogenesis, egg volume increased from $0.216 \pm 0.021 \mathrm{SD}(N=12)$ to $0.305 \pm 0.054$ $\mathrm{SD} \mathrm{m^{3 }}(N=20)$, representing an overall increment of $41.2 \%$. Egg length ranged between 0.765 and $1.213 \mathrm{~mm}$ (average: $0.887 \pm 0.078 \mathrm{~mm}$ ). Females inverted on average $14.90 \pm 3.88 \%$ of their dry weight into egg production, and RO varied between 8.3 and $22.4 \%$. No statistically significant differences were detected for RO values among months (ANOVA, $f=0.05, P>0.05$ ).

\section{Discussion}

Information on the reproductive biology of ghost shrimps generally refers to relatively small sample sizes, and the reported percentage of ovigerous females ranged between 4 and $35 \%$ of all collected individuals (Kevrekidis et al. 1997; Nates and Felder 1999; Berkenbusch and Rowden 2000). Thus, both our sample size (716 individuals) and the percentage of egg carrying females $(6.7 \%)$ are in the range of previously published studies on thalassinidean shrimps. 
Table 2 Ovigerous females of Callichirus seilacheri

\begin{tabular}{|c|c|c|c|c|c|c|}
\hline Month & $\begin{array}{l}\text { Number of } \\
\text { ind. }\end{array}$ & $\begin{array}{l}\text { Carapace length } \\
(\mathrm{mm})\end{array}$ & Egg number & Egg length $(\mathrm{mm})$ & $\begin{array}{l}\text { Seawater } \\
\text { temperature }\left({ }^{\circ} \mathrm{C}\right)\end{array}$ & $\begin{array}{l}\text { Sediment coverage } \\
\text { of burrows }{ }^{\mathrm{a}}\end{array}$ \\
\hline January & - & - & - & - & $18.6 \pm 1.66$ & - \\
\hline February & - & - & - & - & $20.2 \pm 0.72$ & - \\
\hline March & 1 & $22.0 \pm 0.0$ & $19,846 \pm 0.0$ & $1.213 \pm 0.0^{\mathrm{b}}$ & $18.0 \pm 0.85$ & - \\
\hline April & 2 & $20.2 \pm 1.10$ & $13,955 \pm 6,141.9$ & $0.731 \pm 0.032$ & $17.7 \pm 1.52$ & - \\
\hline May & 9 & $21.4 \pm 0.07$ & $15,953 \pm 3,970.5$ & $0.756 \pm 0.045$ & $17.1 \pm 0.77$ & $\mathrm{X}$ \\
\hline June & 11 & $21.4 \pm 0.07$ & $16,347 \pm 3,240.5$ & $0.735 \pm 0.041$ & $16.2 \pm 1.69$ & $X$ \\
\hline July & 7 & $22.2 \pm 0.11$ & $20,585 \pm 4,573.8$ & $0.713 \pm 0.033$ & $15.9 \pm 0.98$ & $\mathrm{X}$ \\
\hline August & 9 & $21.9 \pm 0.07$ & $18,002 \pm 2,656.3$ & $0.775 \pm 0.027$ & $16.1 \pm 1.78$ & $X$ \\
\hline September & 5 & $22.0 \pm 0.15$ & $18,394 \pm 2,773.9$ & $0.736 \pm 0.048$ & $15.8 \pm 0.54$ & - \\
\hline October & - & - & - & - & $17.3 \pm 1.44$ & - \\
\hline November & 2 & $21.9 \pm 0.46$ & $18,347 \pm 6,130.6$ & $0.744 \pm 0.032$ & $17.3 \pm 1.37$ & - \\
\hline December & 2 & $21.5 \pm 0.14$ & $15,833 \pm 3,436.5$ & $0.783 \pm 0.038$ & $17.1 \pm 1.49$ & - \\
\hline Total & 48 & $21.6 \pm 0.83$ & $17,450 \pm 3,796.8$ & $0.749 \pm 0.044$ & $17.3 \pm 1.27$ & \\
\hline$F$ (test value) & & 1.91 & 1.35 & 6.90 & & \\
\hline Probability & & $>0.05$ & $>0.05$ & $<0.001$ & $<0.05$ & \\
\hline
\end{tabular}

Monthly variation of number of collected egg-bearing females, carapace length, number and length of eggs (independent of embryonic development), seawater temperature, and sediment coverage of burrows during of the study period (January-December 2003)

$X$ covered; - not covered

a According to Hernáez and Wehrtmann (2007)

b Eggs in Stage III

According to Coelho et al. (2000), the relatively low number of individuals reported in demographic studies of ghost shrimps might be due to the cryptic life style of these species. It might be speculated that egg-bearing females are situated deeper in the sediment and, thus, not easily accessible to the yabby pump. Another explanation might be related to the polygamist behavior of the species (Hernáez and Wehrtmann 2007), assuming that a male fertilizes only one or a limited number of females of his harem. However, the present contribution was not designed to test these assumptions, and further studies are required to explain the low frequency of ovigerous females in $C$. seilacheri and other thalassinidean shrimps.

The considerable variability among thalassinidean species in fecundity and egg size (Table 3) may indicate important differences in the reproductive strategy, and may also reflect a latitudinal trend as observed in other decapods (Thorson 1950; Sastry 1983; Clarke 1987, 1992; Brante et al. 2004). C. seilacheri produces the highest number of eggs compared to those thalassinideans where data are available. However, this thalassinidean shrimp is the largest species among those listed in Table 3, and it is assumed
Table 3 Carapace length of ovigerous females, and number and length of eggs in some thalassinidean shrimps

n.a. information not available

${ }^{a}$ Obtained from regression equation

\begin{tabular}{lllll}
\hline Species & $\begin{array}{l}\text { Carapace length } \\
(\mathrm{mm})\end{array}$ & $\begin{array}{l}\text { Number of } \\
\text { eggs }\end{array}$ & $\begin{array}{l}\text { Egg length } \\
(\mathrm{mm})\end{array}$ & References \\
\hline Callianassa filholi & $5.5-14.9$ & 1,985 & 0.68 & $\begin{array}{l}\text { Berkenbusch and Rowden } \\
(2000)\end{array}$ \\
C. kraussi & n.a. & 122 & 1.52 & $\begin{array}{l}\text { Forbes (1973) } \\
\text { Thessalou (1987) }\end{array}$ \\
C. tyrrhena & $5.2-10.4^{\mathrm{a}}$ & 270 & 1.18 & Pohl (1946) \\
Callichirus major & n.a. & 8,170 & 0.88 & Present study \\
C. seilacheri & $18.6-23.2$ & 17,450 & 0.88 & Nates et al. (1997) \\
Lepidophthalmus & n.a. & 598 & n.a. & Nates and Felder (1999) \\
$\quad$ louisianensis & $7.0-16.8$ & 251 & 1.22 & Pearse (1945) \\
L. sinuensis & n.a. & 10,000 & n.a. & Tunberg (1986) \\
Upogebia affinis & $16.6-18.9$ & 4,757 & 0.56 & Kevrekidis et al. (1997) \\
U. deltaura & $14.7-16.6$ & n.a. & n.a. & \\
U. pusilla & & & &
\end{tabular}


that the area available for egg attachment increases with female size (Hines 1982; Corey and Reid 1991). When compared to a similar-sized species (Upogebia deltaura: 18.9 mm CL, 5,304 eggs; Tunberg 1986), fecundity in $C$. seilacheri is still substantially higher (18.6 mm CL, 9,612 eggs); moreover, $C$. seilacheri produces considerably larger eggs than $U$. deltaura $(0.884$ and $0.558 \mathrm{~mm}$, respectively). It is speculated that these differences in egg numbers in similar-sized species are related to the elasticity of the abdomen in C. seilacheri (Manning and Felder 1991), which provides more space for egg attachment.

Fecundity in $C$. seilacheri was strongly correlated with carapace length (Table 1). The correlation coefficient (0.89) was substantially higher than those reported for other thalassinidean shrimps (0.55-077; Hanekom and Erasmus 1989; Souza et al. 1998; Berkenbusch and Rowden 2000). However, egg production in C. seilacheri increased allometrically in relation to both female size and weight, which indicates a disproportion among the variables associated with this relation (Somers 1991). This might be related to the different dimensions used for the description of fecundity (volumetric) and female size (linear) (see Somers 1991). We assume that the elasticity of the abdomen of $C$. seilacheri (as described for other ghost shrimps; Manning and Felder 1991) leads to an overestimation of TL, which in turn results in a disproportion of the different biometrical parameters measured (allometry). This interpretation is supported by the observation of Felder and Lovett (1989) who attributed the observed allometric increase between gonad weight and female size of Lepidophthalmus lousianensis to the elasticity of the abdomen.

Egg length of $C$. seilacheri is relatively low when compared to other thalassinidean species (Table 3). It has been demonstrated that egg size is correlated with both the duration of embryogenesis and the size of hatchlings (Steele and Steele 1975; Wehrtmann and López 2003). Regarding thalassinideans, the available information demonstrate that species with an abbreviated larval development such as Callianassa kraussi (Forbes 1973), C. tyrrhena (Thessalou et al. 1999) and L. sinuensis (Nates et al. 1997) produce larger eggs than those with extended larval development (C. filholi: $0.68 \mathrm{~mm}$, Berkenbusch and Rowden 2000). According to Aste and Retamal (1983), the larval development of $C$. seilacheri consists of five larval stages; thus our egg volume data confirm that relatively small eggs indicate a prolonged larval period.

Egg loss in C. seilacheri was insignificant when compared to the thalassinidean shrimp Calocaris macandrae (66\%; Buchanan 1963) and other decapods (for review, see Kuris 1991). During embryogenesis, C. seilacheri lost $8.6 \%$ of the initially produced eggs, while the egg volume increased by more than $40 \%$. In accordance with other studies on egg production in decapods (Kuris 1991), it is assumed that—due to limited space for attachment-the swelling of the eggs during embryogenesis results in a reduction of the number of incubated eggs.

Females of C. seilacheri inverted $14.9 \%$ of their body weight into the production of eggs. This value is slightly lower than that reported for C. tyrrhena $(19.6 \%$, Thessalou and Kiortsis 1997), but in the range of RO values (3-22\%) described for brachyuran crabs (Hines 1991; Brante et al. 2004) and higher than those published for anomurans (3-10\%; Lardies and Wehrtmann 1996; Hernáez and Palma 2003). Additional RO data for thalassinidean shrimps are needed to test whether the species' cryptic life may allow for a higher energy allocation to reproduction.

The reproductive cycle of many decapods, especially of those in temperate and cold-water zones, is synchronized with the temporal variation of environmental factors such as temperature, photoperiod, and food availability (Clarke 1987; Bauer 1992; Kevrekidis et al. 1997; Berkenbusch and Rowden 2000; Lardies et al. 2004). In our study the number of collected ovigerous females increased with decreasing temperatures, which coincided with the period when the burrow entrances of $C$. seilacheri were usually covered by a sediment layer. However, the mechanism of providing sufficient oxygen for the embryos inside the covered burrow remains to be studied.

Acknowledgments The first author $(\mathrm{PH})$ is grateful to the Universidad Arturo Prat, Iquique, Chile, especially the Museo del Mar, for providing facilities to analyze the collected material. We greatly appreciate the critical comments by Fresia Villalobos and Yurlandy Gutierrez on an earlier draft of the manuscript, which helped to improve the manuscript.

\section{References}

Aste A, Retamal MA (1983) Desarrollo larval de Callianassa garthi Retamal, 1975 bajo condiciones de laboratorio. Cienc Technol Mar 7:5-26

Bauer RT (1992) Testing generalizations about latitudinal variation in reproduction and recruitment patterns with sicyoniid and caridean shrimp species. Invertebr Reprod Dev 22:193-202

Berkenbusch K, Rowden AA (2000) Latitudinal variation in the reproductive biology of the burrowing ghost shrimp Callianassa filholi (Decapoda, Thalassinidea). Mar Biol 136:497-504

Berkenbusch K, Rowden AA (2003) Ecosystem engineering: moving away from just-so stories. $\mathrm{N} Z \mathrm{~J}$ Ecol 27:67-73

Bilodeau AL, Felder DL, Neigel JE (2005) Multiple paternity in the thalassinidean ghost shrimp, Callichirus islagrande (Crustacea, Decapoda, Callianassidae). Mar Biol 146:381-385

Bott R (1955) Litorale Dekapoden, ausser Uca. Dekapoden (Crustacea) aus El Salvador, 2. Senckenbergiana Biol 36:45-70

Brante A, Cifuentes S, Pörtner HO, Arntz W, Fernández M (2004) Latitudinal comparisons of reproductive traits in five brachyuran species along the Chilean coast. Rev Chil Hist Nat 77:15-27

Buchanan J (1963) The biology of Calocaris macandrae (Crustacea, Thalassinidea). J Mar Biol Assoc UK 43:729-747 
Clarke A (1987) Temperature, latitude and reproductive effort. Mar Ecol Prog Ser 38:89-99

Clarke A (1992) Reproduction in the cold: Thorson revisited. Invertebr Reprod Dev 22:175-184

Clarke A, Hopkins CC, Nilssen EM (1991) Egg size and reproductive output in the deep water prawn Pandalus borealis Kroyer, 1838. Funct Ecol 5:724-730

Coelho V, Cooper RA, Rodrigues S (2000) Burrow morphology and behaviour of the mud shrimp Upogebia omissa (Decapoda, Thalassinidea, Upogebiidae). Mar Ecol Prog Ser 200:229-240

Corey S, Reid DM (1991) Comparative fecundity of decapod crustaceans. The fecundity of thirty three species of nine families of caridean shrimps. Crustaceana 60:270-294

Felder DL, Griffis RB (1994) Dominant infaunal communities at risk in shoreline habitats: burrowing thalassinid Crustacea. OCS Study MMS 94-0007. US Dept. of the Interior, Minerals Mgmt. Service, Gulf of Mexico OCS Regional Office, New Orleans, Los Angeles

Felder DL, Lovett DL (1989) Relative growth and sexual maturation in the estuarine ghost shrimp Callianassa louisianensis Schmitt, 1935. J Crust Biol 9:540-553

Forbes AT (1973) An unusual abbreviated larval life in the estuarine burrowing prawn Callianassa kraussi (Crustacea, Decapoda, Thalassinidea). Mar Biol 22:361-365

Hanekom N, Erasmus T (1989) Determinations of the reproductive output of populations of a thalassinid prawn Upogebia africana (Ortmann) in the Swartkops estuary. S Afr J Zool 24:244-250

Hernáez P, Palma S (2003) Fecundidad, volumen del huevo y rendimiento reproductivo de cinco especies de porcelánidos intermareales del norte de Chile (Decapoda, Porcellanidae). Invest Mar Valparaíso 31:35-46

Hernáez P, Wehrtmann IS (2007) Population biology of the burrowing shrimp Callichirus seilacheri (Decapoda, Thalassinidea, Callianassidae) in northern Chile. Rev Biol Trop 55:141-152

Hines AH (1982) Allometric constraints and variables of reproductive effort in brachyuran crabs. Mar Biol 69:309-320

Hines AH (1991) Fecundity and reproductive output in nine species of Cancer crabs (Crustacea, Brachyura, Candridae). Can J Fish Aquat Sci 48:267-275

Kevrekidis T, Gouvis N, Koukouras A (1997) Population dynamics, reproduction and growth of Upogebia pusilla (Decapoda, Thalassinidea) in the Evros delta (North Aegean Sea). Crustaceana 70:799-812

Kuris A (1991) A review of patterns and causes of crustacean brood mortality. In: Schram FR (ed) Crustacean issues, vol 7. Balkema, Rotterdam, pp 117-141

Lardies MA, Wehrtmann IS (1996) Aspects of the reproductive biology of Petrolisthes laevigatus (Guerin, 1835) (Decapoda, Anomura, Porcellanidae). Part I: reproductive output and chemical composition of eggs during embryonic development. Arch Fish Mar Res 43:121-135

Lardies MA, Rojas JM, Wehrtmann IS (2004) Breeding biology and population structure of the intertidal crab Petrolisthes laevigatus (Anomura, Porcellanidae) in central-southern Chile. J Nat Hist 38:375-388

Manning R, Felder DL (1991) Revision of the American Callianassidae (Crustacea, Decapoda, Thalassinidea). Proc Biol Soc Wash 104:764-792

Nates SF, Felder DL (1999) Growth and maturation of the ghost shrimp Lepidophthalmus sinuensis Lemaitre and Rodrigues, 1991 (Crustacea, Decapoda, Callianassidae), a burrowing pest in penaeid shrimp culture ponds. Fish Bull 97:526-541

Nates SF, Felder DL, Lemaitre R (1997) Comparative larval development in two species of the burrowing ghost shrimp genus Lepidophthalmus (Crustacea, Decapoda, Callianassidae). J Crust Biol 17:497-519

Pearse AS (1945) Ecology of Upogebia affinis (Say). Ecology 26:303-305

Pianka ER (1972) $R$ and $K$ selection or $b$ and $d$ selection? Am Nat 106:581-588

Pohl ME (1946) Ecological observations on Callianassa major Say at Beaufort, North Carolina. Ecology 27:71-80

Reid DM, Corey S (1991) Comparative fecundity of decapod crustaceans. II. The fecundity of fifteen species of anomuran and brachyuran crabs. Crustaceana 61:175-189

Retamal MA (1975) Descripción de una nueva especie del género Callianassa y clave para reconocer las especies chilenas. Bol Soc Biol 49:177-183

Sakai K (1999) Synopsis of the family Callianassidae, with keys to subfamilies, genera and species, and the description of new taxa (Crustacea, Decapoda, Thalassinidea). Zool Verhand 326:1-152

Sastry AN (1983) Ecological aspects of reproduction. In: Vernberg FJ, Vernberg WB (eds) The biology of Crustacea. Environmental adaptations. Academic Press, New York, pp 213-282

Somers K (1991) Characterizing size-specific fecundity in crustaceans. In: Schram FR (ed) Crustacean egg production. Crust Issues 7. A.A. Balkema, Rotterdam, The Netherlands, pp 357378

Soto R, Muñoz S, Moreno R (2002) Biological background of "El Niño" and "La Niña" in intertidal and subtidal communities of the northern zone of Chile. Invest Mar Valparaíso 30:160-162

Souza J, Borzone C, Brey T (1998) Population dynamics and secondary production of Callichirus major (Crustacea, Thalassinidea) on a southern Brazilian sandy beach. Arch Fish Mar Res 46:151-164

Steele DH, Steele VJ (1975) Egg size and duration of embryonic development in Crustacea. Int Rev Ges Hydrobiol 60:711-715

Thessalou M (1987) Contribution to the study of ecology and biology of the shrimp Callianassa tyrrhena (Petagna, 1792) (in Greek). (Crustacea, Decapoda, Thalassinidea). Ph.D. Thesis, University of Athens, Athens, Greece

Thessalou M, Kiortsis V (1997) Estimation of the reproductive output of the burrowing shrimp Callianassa tyrrhena: a comparison of three different biometrical approaches. Mar Biol 127:435-442

Thessalou M, Peppa A, Zacharaki M (1999) Facultative lecithotrophy during larval development of the burrowing shrimp Callianassa tyrrhena (Decapoda, Callianassidae). Mar Biol 133:635-642

Thorson G (1950) Reproductive and larval ecology of marine bottom invertebrates. Biol Rev 25:1-45

Tunberg B (1986) Studies on the population ecology of Upogebia deltaura (Leach) (Crustacea, Thalassinidea). Estuar Coast Shelf Sci 22:753-765

Turner RL, Lawrence JM (1979) Volume and composition of echinoderm eggs: implications for the use of egg size in life history models. In: Stancik SE (ed) Reproductive ecology of marine invertebrates. The Belle W. Baruch Library Mar Sci 9, Univ South Carolina Press, Columbia, pp 25-40

Wehrtmann IS (1990) Distribution and reproduction of Ambidexter panamense and Palaemonetes schmitti in Pacific Costa Rica (Crustacea, Decapoda). Rev Biol Trop 38:327-329

Wehrtmann IS, Kattner G (1998) Changes in volume, biomass, and fatty acids of developing eggs of Nauticaris magellanica (Decapoda, Caridea): a latitudinal comparison. J Crust Biol 18:413-422

Wehrtmann IS, López GA (2003) Effects of temperature on the embryonic development and hatchling size of Betaeus emarginatus (Decapoda, Caridea, Alpheidae). J Nat Hist 37:2165-2178

Zar JH (1999) Biostatistical analysis. Upper Saddle River, New Jersey 